\title{
Research on the Connotation of Moral Life Education in Schools for the Mental Retardation, Existing Problems and Corresponding Strategies
}

\author{
Jihai Shi \\ Education Scientific Research Institute, Binzhou, China \\ Email: shijihai5564@163.com
}

How to cite this paper: Shi, J. H. (2017). Paper Title Research on the Connotation of Moral Life Education in Schools for the Mental Retardation, Existing Problems and Corresponding Strategies. Creative Education, 8, 2508-2514.

https://doi.org/10.4236/ce.2017.815173

Received: November 30, 2017

Accepted: December 23, 2017

Published: December 26, 2017

Copyright $\odot 2017$ by author and Scientific Research Publishing Inc. This work is licensed under the Creative Commons Attribution International License (CC BY 4.0).

http://creativecommons.org/licenses/by/4.0/ (c) (i) Open Access

\begin{abstract}
Education's essence is life education and its core is life development. Meanwhile, morality serves as an important component of life, and the development of human life is inseparable from morality. Naturally, life education and moral education are both essential and indispensable and in turn moral life education becomes the inevitable logical choice in life education. The moral life education in schools for the Mental Retardation, based on mentally retarded children's need for life development and guided by moral education, fully carries out education of life awareness, life meaning and life value on the basis of cultivating students' survival skill. However, at present, the moral life education in schools for the Mental Retardation tends to neglect students' life awareness, life freedom and their spiritual life while overemphasizing the cultivation of survival skills. In view of the status quo, on the premise of ensuring the subjectivity of moral life education, only by combining classroom education with education outside class and securing cooperation between school and families can students' life awareness be gradually aroused and moral life education enjoy harmonious development. The moral life education in schools for the Mental Retardation is a matter of mentally retarded children's dignity, meaning and value of existence. Therefore, it is of great significance to accurately grasp moral life education's connotation, existing problems and corresponding strategies, contributing to students' integrating into the society smoothly.
\end{abstract}

\section{Keywords}

School for the Mental Retardation, Moral Life, Education, Connotation, Problems and Strategies 


\section{Introduction of Problems}

Education is a social activity that cultivates talents. The essence of education lies in life education with the core of it life development. Life education, in a sense, is to guide students to form an accurate understanding of life and existence value through various kinds of education activities and to face depression and pains in life with a positive attitude. Students are taught to revere life, respect life, and cherish life, thus facilitating their healthy personality development ( $\mathrm{Li}, 2006)$. Such kind of life education focuses more on natural life with little attention paid to moral life education. In fact, morality comes from life whether in terms of its origin or motive force of development. Not only is human beings' life a natural growth process, but it is a process of moralization, humanization and socialization, and a process of moral involvement and moral enlightenment. Without morality, life development will be out of order and one's dignity and life value will be lost. That is to say, morality dwells in life. Moral life education, based on the need for life development, aims to promote life development, strengthen the meaning of life and realize an ideal life (Feng, 2014). Moral life education in schools for the Mental Retardation aims at promoting a sound life development of mentally retarded children, thus helping children shape a correct outlook on life and values-caring for life, loving life and treasuring life, integrate into the society smoothly and become a member of the society with dignity. Nonetheless, moral life education in schools for the Mental Retardation overemphasizes the cultivation of survival ability and pays too much attention to the existence of secular life, but neglects the education of life awareness and life value and the spiritual life of mentally retarded children. Therefore, it is an incomplete education which departs from the essence of moral life education. Based on such a status quo, this thesis will uncover the existing problems in moral life education in schools for the Mental Retardation and explore certain effective measures to advance the moral life education for mentally retarded children.

No doubt it is of highly practical significance to gain a profound understanding of the connotation and essence of moral life education in schools for the Mental Retardation, grasp the strategic construction and handle the imbalances in the process of implementation so as to fulfill the comprehensive and harmonious development of moral life education, promote the healthy growth of mentally retarded children's natural life and moral life and realize holistic education (Feng, 2009).

\section{Connotation of Moral Life Education of the School for the Mental Retardation}

Life education originates from USA with an American scholar Donald Walters putting forward the life education in 1968. His idea was initially a result of such phenomenon as drug taking, suicide, homicide and sexploitation, aiming to arouse individuals' love for life and eliminate threats to life. Western life education is mainly oriented towards life health education, preventing violence 
and epidemic diseases, and ensuring life safety and physical and psychological health. However, Chinese scholars hold different opinions towards life health education. The Provisional Guideline of the Nine-Year Curriculum for Primary and Secondary Schools issued in Taiwan in 2001 defines life education as the cultivation of individuals' respect for life by observing birth, senility, illness and death and sharing feelings towards them so that they can obtain a deeper understanding of the meaning of life and the value of existence. In Hong Kong, education is mainly carried out from the aspect of religion, covering religious education, moral education, ethic and civic education etc., as is revealed in such articles as Life Education in Hong Kong. As is pointed out in the Guidelines of the National Program for Medium- and Long-Term Educational Reform and Development, safety education, life education, national defence education and education for sustainable education are supposed to be stressed. According to the Report of the Third Plenary Session of the 18th CPC Central Committee, it advocates comprehensively implementing the Party's educational policy, strengthening moral education and cultivating people, enhancing the education of socialist core value system, perfecting the education of excellent traditional Chinese culture, forming a long-term activity mechanism featuring love for study, work and the country as well as intensifying students' sense of social responsibility, spirit of innovation and practical ability. Under this report, we can see that our country attaches much importance to life education and moral education. But it was Mr. Jianjun Feng who combined life education with moral education, expounded them from the logic level and feasibility level and put forward the concept of moral life education. In his paper, he proposed constructing moral life education for the first time who claimed moral life education was not moral education but life education highlighting moral concern. It not only focused on the existence of life but also the spiritual meaning of life to promote people's ability to survive and enjoy life. Under such perspectives, moral life education in schools for the Mental Retardation, based on mentally retarded children's need for life development, should carry out education of life awareness, life significance and life value to the maximum apart from emphasizing the cultivation of students' survival skills so as to return moral education to real life, ending up achieving integration of moral life education.

\section{The Existing Problems of Moral Life Education in Schools for the Mental Retardation}

While sharing certain common features with that in ordinary schools, moral life education in schools for the Mental Retardation possesses certain special characteristics due to its special teaching objects. Moral life education in schools for the Mental Retardation, because of mentally retarded children's special life development, overemphasizes the education of survival skills while neglects the guidance of life awareness, life right and the value of life, ending up deviating from the wholeness of moral life education. 


\subsection{The Neglect of Students' Life Awareness}

Human existence is not only bodily existence but conscious existence. In Marx's view, the value of human existence contains three basic characteristics, namely, the uniformity of human existence and nature existence, the uniformity of human existence and social existence, the uniformity of human being and self in the process of self-value realization. That is to say, we human beings can consciously control our own life, a conscious life. Therefore, men need life education and need to know why they live. In the ontological sense, life education is not a result of life-threatening problems, such as suicide, AIDS, drugs, which instead, is an education of life meaning, or that of outlook on life and value (Feng, 2014). Nevertheless, in real moral life education in schools for the Mental Retardation, the education of individual existence value is often ignored and students are not well guided to understand the meaning of life, resulting in students' misconception of it. In their mind, to live is to eat. Considering such a status quo, it is necessary for schools for the Mental Retardation to guide mentally retarded children to understand the meaning of life and arouse their cognition of the social existence of life and life consciousness, thus returning to the essence of moral life education.

\subsection{The Overemphasis of Cultivating Students' Survival Skills}

The particularity of mentally retarded children's physical and mental development in schools for the Mental Retardation determines its different development focus and direction of moral life. Both schools and teachers tend to pour their attention to cultivating students' survival skills. In their eyes, what matters most is that mentally retarded students master certain skill to ensure their smooth integration into the society with a stable job, which on the one hand eases the burden of their family and on the other hand tempers the children to be self-supported individuals. There is no denying that these schools and teachers' behavior is commendable to some extent especially in such a competitive employment market. However, to better integrate into the world, these kids require moral life development. Anyway, overemphasizing students' survival skills but ignoring their moral life education is detrimental to mentally retarded students' healthy and harmonious growth.

\subsection{The Deprivation of Students' Life Freedom}

In real world, schools for the Mental Retardation offer students the place to study, laying a solid material foundation for mentally retarded students' further development. On the other hand, due to these schools' concern about mentally retarded students' physiological defects, a series of protective measures, to a certain degree, limit students' life development potential. To maintain the life management order and ensure students' safety, such schools strictly discipline students, thus restraining students' freedom. From the perspective of schools, students should obey the regulations. When students commit disciplinary of- 
fences, schools just force them to acknowledge their misconducts and accept punishment rather than reflect upon why they violate the discipline or whether it is reasonable to do so. Such kind of moral life education featuring absolute obedience greatly weakens students' vitality, deprives individuals of the right to pursue freedom and diversity and kills one's countless life development possibilities (Mao, 2008). Therefore, such moral life education is harmful to students' health harmonious development.

\subsection{The Ignorance of Students' Spiritual Life}

Admittedly, the idea of student-oriented teaching has been gradually adopted in teaching practices. However, with regard to current moral life education in schools for the Mental Retardation, although it has undergone some reforms, students are not seen as the subjects in teaching practice and instead are passive receivers. Students' subjectivity hasn't been upgraded to the level of life meaning. The so-called subjectivity refers to the qualitative property of a person as the center of the activity, the integrated feature of freedom, independence and transcendence developed in the process of interactions with the object (Wu, 2009). If a person' life is a combination of natural life and spiritual life, then spiritual one is an integration of one's value life and social life. Spiritual life embodies kindness, which is a favorable upward force. In a sense, subjectivity is the manifestation and core feature of spiritual life. Speaking of the moral life education in schools for the Mental Retardation, it in fact is still striving to cultivate some self-supported individuals who can smoothly integrate into the society though it has been advocating student autonomy in the process of education. So, the students still receive a passive education and their spiritual lives are to some extent destroyed.

\section{Strategies for Ameliorating Moral Life Education in Schools for the Mental Retardation}

The newly-revised Regulation on the Education of the Disabled highlights the disabled's compulsory education and presents higher requirements in implementing moral life education in schools for the Mental Retardation. Reconstructing the value of moral life education in schools for the Mental Retardation is of great directive significance to promote the healthy and harmonious development of mentally retarded students' moral life.

\subsection{The Gradual Awakening of Students' Moral Life Awareness}

As the core of education is life development, the education in schools for the Mental Retardation must awaken students' moral life awareness to further students' life development and form students' overall understanding of both the basic features of their own life and the evolution and perfection mechanism of life. The formation of such moral life awareness enables students to face up to individual lives and meanwhile develop moral concerns. But in the course of 
people's life development and growth, the value of moral life doesn't display itself. Hence, teachers in schools for the Mental Retardation are supposed to make use of concrete cases to let students come to realize the finiteness of life existence and the infiniteness of moral life, thus facilitating the growth of moral life.

\subsection{The Accurate Understanding of Subjectivity in Moral Life Education}

The process of moral life education is that of individuals' spiritual life improvement. One's spiritual life can't develop without the liberation of his autonomy, originality and self-transcendence. Therefore, human beings' subjectivity shares commensurability with spiritual life beyond freedom, autonomy and transcendence (Wu, 2009). The realization of subjectivity, in a large sense, is the self-realization of life meaning and the manifestation of spiritual life. In turn, in the process of moral life education in schools for the Mental Retardation, teachers should bring students' subjectivity into full play, letting students gain a thorough understanding of themselves, develop themselves and display themselves. By having their subjectivity brought into full play, students discover and find themselves while passively receiving moral life education, ending up realizing self-fulfillment objective.

\subsection{The Combination of Class Teaching Penetration and Real Life Education}

The traditional classroom teaching in schools for the Mental Retardation is inclined to teach students much theoretical knowledge, resulting in their living a relatively unsatisfactory life after stepping into the society. As not having been equipped with the basic living and working skills and lacking the guidance of moral behaviors when leaving school, students' development in moral life is confined. With the deepening of new curriculum reform, students' need gradually becomes the essential requirement of curriculum reform. In view of this, courses offered to students should overcome the knowledge-oriented defect, and classroom teaching should be based on survival, return to life and simultaneously pay attention to life existence and morality. For this purpose, content of moral life should be penetrated into classroom teaching. Besides, abiding by Mr. Xingzhi Tao's ideology—life is education, teachers should link moral life education with real life and let the kids practice repeatedly through small group teaching, scene practice and individual instruction, thus helping enrich students'

life experience gradually and promoting every child's healthy development of moral life.

\subsection{The Promotion of Harmonious Development of Survival Education and Life Value Education}

One needs to learn to survive to live. Survival education just echoes the real society's demand, aiming to help students better adapt to the society and become competitive individuals. The existence of human beings includes natural exis- 
tence and social existence, so survival education deals with not only living skills but also social skills and moral rules. Definitely, human beings' life is far from being alive alone. In German Philosopher Hershel's words, human beings' existence is never a pure existence which always has something to do with life meaning (Herschel, 1998). In other words, everyone's life is a meaning existence and hence the education of life value is of vital importance. As has been mentioned above, the moral life education in schools for the Mental Retardation centers on teaching survival skills while ignores the education of life value. Moral life education is not only an education living up to the real society's demand but one pursuing life meaning and demonstrating life value. Only by well combining survival education and life value education can mentally retarded children live a meaning and valuable life with dignity after stepping into the society.

\subsection{The Emphasis of Cooperation between School Education and Family Education}

Family is considered as kids' first place to receive education. Studies indicate that family environment greatly affects the formation of kids' personality. In kids' growth process, family education always plays a key role. Students' growth in schools for the Mental Retardation has much to do with family education as well, with parents' words and behaviors and parenting styles impacting kids' healthy growth. Schools can offer scientific guidance to families by founding parent school and parent education committee, or holding lectures on family education. What's more, class teachers are supposed to communicate students' moral life development with parents in time so as to gain an overall understanding of students' strong points and drawbacks and thus take different measures. By closely combining school education and family education, schools for the Mental Retardation will ensure a sound development of students' moral life education.

\section{References}

Feng, J. J. (2009). Life Education and Life Integration. Educational Theory and Practice, 8, 10.

Feng, J. J. (2014). Moral-Oriented Life Education. Educational Research, 6, 38.

Herschel, W. (1998). Who is Man. Guiyang: Guizhou People’s Publishing House, 46.

Li, J. M. (2006). The Emphasis on Life Education in Modern Moral Education. School Party Construction and Ideological Education, 7, 50.

Mao, G. X. (2008). Life Value Orientation of Moral Education in Schools. Journal of Suzhou Education Institute, 4, 23.

Wu, X. X. (2009). On Subjective Moral Education in Life Education Philosophy. Education Academic Monthly, 1, 73-74. 